2003

\title{
Kuhn's paradigm as a parable for the Cold War: incommensurability and its discontents from Fuller's Tale of Harvard to Fleck's Unsung Lvov
}

Babette Babich

Fordham University, babich@fordham.edu

Follow this and additional works at: https://fordham.bepress.com/phil_babich

Part of the Continental Philosophy Commons, Philosophy of Science Commons, Political Theory Commons, Politics and Social Change Commons, Science and Technology Studies $\underline{\text { Commons, }}$ Sociology of Culture Commons, and the Theory, Knowledge and Science Commons

\section{Recommended Citation}

Babich, Babette, "Kuhn's paradigm as a parable for the Cold War: incommensurability and its discontents from Fuller's Tale of Harvard to Fleck's Unsung Lvov" (2003). Articles and Chapters in Academic Book Collections. 8.

https://fordham.bepress.com/phil_babich/8 
This article was downloaded by:[Ingenta Content Distribution]

On: 23 December 2007

Access Details: [subscription number 768420433]

Publisher: Routledge

Informa Ltd Registered in England and Wales Registered Number: 1072954

Registered office: Mortimer House, 37-41 Mortimer Street, London W1T 3JH, UK

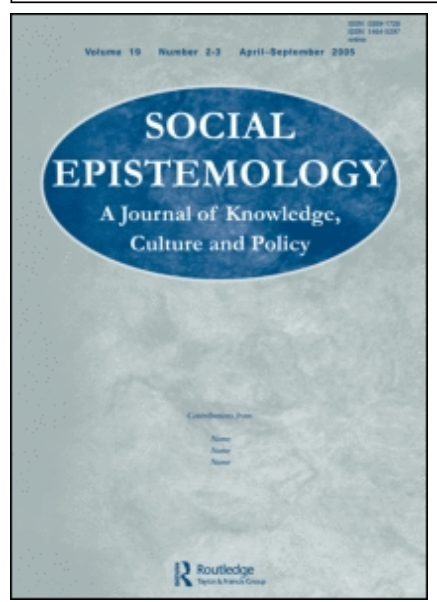

\section{Social Epistemology}

A Journal of Knowledge, Culture and Policy

Publication details, including instructions for authors and subscription information: http://www.informaworld.com/smpp/title content=t713765921

Kuhn's paradigm as a parable for the Cold War: incommensurability and its discontents from Fuller's Tale of Harvard to Fleck's Unsung Lvov

Babette E. Babich ${ }^{\text {a }}$

${ }^{a}$ Fordham University, New York City, and Georgetown University, Washington, DC, USA.

Online Publication Date: 01 January 2003

To cite this Article: Babich, Babette E. (2003) 'Kuhn's paradigm as a parable for the Cold War: incommensurability and its discontents from Fuller's Tale of Harvard to

Fleck's Unsung Lvov', Social Epistemology, 17:2, 99 - 109

To link to this article: DOI: $10.1080 / 0269172032000144018$

URL: http://dx.doi.org/10.1080/0269172032000144018

\section{PLEASE SCROLL DOWN FOR ARTICLE}

\section{Full terms and conditions of use: http://www.informaworld.com/terms-and-conditions-of-access.pdf}

This article maybe used for research, teaching and private study purposes. Any substantial or systematic reproduction, re-distribution, re-selling, loan or sub-licensing, systematic supply or distribution in any form to anyone is expressly forbidden.

The publisher does not give any warranty express or implied or make any representation that the contents will be complete or accurate or up to date. The accuracy of any instructions, formulae and drug doses should be independently verified with primary sources. The publisher shall not be liable for any loss, actions, claims, proceedings, demand or costs or damages whatsoever or howsoever caused arising directly or indirectly in connection with or arising out of the use of this material. 


\title{
Kuhn's paradigm as a parable for the Cold War: incommensurability and its discontents from Fuller's Tale of Harvard to Fleck's Unsung Lvov
}

\author{
BABETTE E. BABICH
}

If Thomas Kuhn ever truly understood it or not, he certainly could not abide the extraordinary influence that was and is the conceptual legacy of his The Structure of Scientific Revolutions. For Steve Fuller, author of Thomas Kuhn: A Philosophical History for Our Times, this diffidence was not a character flaw but the literally venerable sign of sanctity. As a 'saint', to use Fuller's expression, Kuhn renounces the fame and the influence he had won, condemning it, sicut palia, as straw, ashes-all that stuff to which so many mere mortals would aspire. I am charmed by this interpretation if it does not entirely persuade me. This is not just because I do not share Fuller's (only relatively closeted) enthusiasm for values, religious and otherwise. ${ }^{1}$ Rather, as I shall argue, Kuhn himself never grasped what he had wrought: not because the ideas of genius here exceeded (as they often exceed) the individual of genius, but, and quite routinely, because they weren't altogether Kuhn's ideas in the first place.

Fuller is more than a little cavalier in his reference to thinkers and their associated expert contexts so that apart from Kuhn and Conant (in the context of an admirably Peyton Place style reading of an erstwhile Cambridge, Mass. experience) Fuller is not as fair as he might be. Thus from Koyré to Yates to Mach (but excluding Planck and Duhem, both of whom Fuller seems to like) but also Mannheim and Gombrich and most worrisomely, Feyerabend (who was, for many years, my own good friend and correspondent), Fuller evinces a storyteller's smoothness but insufficient exigence. Thus, for example, Fuller reduces Feyerabend to a pastiche of his 'Anything goes' slogan. ${ }^{2}$ And he does this largely to avoid the dangers of that same 'irrationalism' to which Feyerabend openly 'converted' (Fuller 2000, p. 304). But Fuller owes Feyerabend a bit more than this for Fuller's social-historical reading of Galileo (pp. 187 ff.) is markedly indebted to Feyerabend, as it also owes something to Patrick A. Heelan. Heelan is a Jesuit physicist and philosopher of science known to both Fuller and myself from Heelan's influence on us in our student days: mine as an undergrad at Stony Brook,

Author: Babette E. Babich, Fordham University, New York City, and Georgetown University, Washington, DC, USA. 
Fuller as a grad student whose energy and impatience bemused Heelan during his short stint as a visiting Fellow at Pittsburgh. If Fuller's effort to downplay Feyerabendian associations is an anxious one, in a Bloomian sense, Fuller's failure to refer to Heelan is all too routine. ${ }^{3}$

Rather than here reprising Fuller's study of Thomas Kuhn (not that I could do justice to Fuller's magisterial treatment in such a brief essay and because in any case redundant in the present context), I examine a single aspect of Fuller's book for the sake of a corrective review of the relationship between Ludwik Fleck and Thomas Kuhn. Fuller, for his part, understates the role of Fleck's influence on Kuhn and suggests that, at best, such an influence should be referred to sociological theories proximally derived from Mannheim and endorsing Thaddeus Trenn's account in the English translation of Fleck's work. ${ }^{4}$ Because Fuller's book is impressively exhaustive, his incidental (i.e. footnote-level) dismissal of Fleck's (never very highly touted) influence deserves a bit of re-reading and that is what I undertake below. ${ }^{5}$

It was not N.R. Hanson's point in his description of the differing profiles presented by the same laboratory for a scientist as contrasted with an extern's experience of that same scene, that one's presuppositions (Hans-Georg Gadamer calls these one's 'prejudices') influence perception. ${ }^{6}$ But that influence would be the hermeneutic point. Such prejudices are the limits of the world one brings to the world one finds. Philosophers of science tend to be less than receptive to Kuhn and Kuhn himself internalised that same reception at what must have been a signal price of considerable cognitive dissonance and as manifest in his person throughout his life, and we will return to this below. But it was as a philosopher of science that Robert S. Cohen, a man both influential in philosophy of science and one quite open to names like Fleck's (and even Nietzsche's), could react as he did, namely with more than a little violence when I once asked him about Kuhn. If Steve Fuller corrects that, he also surprisingly, i.e. given his own STS interests, marginalises an exactly social history of science in failing to attend in any detail to Fleck's The Genesis and Development of a Scientific Fact.

\section{The 'Science Wars'-or the Anxiety of Influence: C.I. Lewis vs. Fleck}

In what follows, I argue that Kuhn's limited acknowledgment of Fleck's influence on his The Structure of Scientific Revolutions was due to a foundational incommensurability between the standard conceptual framework for philosophical studies of science and Fleck's historico-social and praxis-oriented approach to scientific progress. The incommensurability in question constituted an insurmountable tension between the kind of language and thinking manifest in Fleck's study and the conceptual language evident in Kuhn and characteristic of one might still call the 'received view' in philosophy of science. This (ongoing) 'reception' of ideas and language is the reason Fuller attributes the language of 'incommensurability' (or the talk of different 'worlds') in the philosophy of science to C.I. Lewis's tacit influence. ${ }^{8}$ It is not irrelevant that this esoteric (or, in this case, insider's) reference captures Fuller's interest to a far greater degree than does Fleck's more marginal (and not incidentally outsider's) role in the philosophy of science. Thus commentary on Fleck tends not to focus on his account of scientific progress but to review the neglect of this same account. The English-language translation of Fleck's 1935 
study (1979) only came about in answer to this neglect and it is conceivable that, had no one noticed the parallels between Fleck's and Kuhn's views on the communal dynamic of scientific practice in Kuhn (1970 [1962]), as German scholars did do, largely beginning with Wilhelm Baldamus who set Thomas Schnelle on a research task that became his own life's work in the process (Schnelle 1982), Fleck's work might never have seen the light of day in English. ${ }^{9}$

Fleck's conception of thought communities (conceived as functioning throughout history as well as contemporaneously in modern scientific research practice), challenges Western liberal ideas of individualism and freedom. ${ }^{10}$ Maintaining that scientific truth is ineluctably social, Fleck takes the disciplinary relevance of sociology of knowledge to be no less central to an understanding of science than history itself. Yet adverting to the sociology of science (in particular) or else (more broadly) to the history of science compounds the troubles of incommensurability.

Thus it is important that sociology of science per se, apart from distant disciplinary icons like Robert Merton, but qua sociological studies, qua quintessentially social science, has yet to enjoy an uncontested status vis-à-vis 'science' proper, i.e. natural science. Nor is this particularly remarkable because, historically, the social sciences in their current 'scientific' form are younger than the natural sciences and were quite conscientiously formed in that same, mathematised image. ${ }^{11}$

But and exactly in the wake of the 'science wars', sociology has been compelled to defend itself precisely as a science. ${ }^{12}$ The history of science itself remains a methodological and conceptual problem for philosophy of science and the rational ideal of science because (unlike other 'social' studies of science) the history of science refers very precisely to the way science 'in fact' (as one might say) was generated and how science actually or factually developed in real scientific practice. But beyond sociological studies and more than anything else, it may be argued, new approaches to the history of science (deriving from conceptual changes in the doing of history itself) have begun (although this task is far from complete) to undermine the standard or received view of analytic philosophy of science. ${ }^{13}$

In the context of social theories of scientific culture, it is important if not without controversy, to advert to the camp quality of the Sokal hoax that inaugurated the socalled 'science wars' (though who indeed actually fought about anything in any of these so-called wars remains an unasked question). Although the 'science wars' bear directly on Fuller's reading of Kuhn, Fuller himself makes only oblique reference to Sokal's hoax as such.

Throughout the past century, both critics and proponents of science alike have been invited to accept or receive only what certified scientists endorse as an authorised definition of science. This, of course, is the joke that originally played in the staging of the hoax as a game played upon the editors of Social Text-precisely as an insider's joke, played on and among friends. In other words, there was no 'hoax'-properly speaking. The hoax itself was a hoax, a joke, a bit of camp. A double hoax, Sokal's hoax was effected by means of an exact 'in' on the game. It is a relevant bit of evidence (or gossip, as I heard it from no one less than Fuller himself) ${ }^{14}$ that Sokal was a friend of Social Text editor and meteorological enthusiast, Andrew Ross, that Sokal met his current wife at a party at Ross's homeand that all this is relevant because exactly not nothing follows from such social or friendly circumstantial evidence. Academics who know editors should know better 
than to think that any kind of vetting or review-blind or expert, humanist or scientist, or what have you-would or could be at work in such friendly cases. Almost too trivially good to be true, it wasn't: the hoax was 'cooked'-it was a thoroughly academic set-up.

An overawed confidence in the ultimacy of current physical science is at work in Sokal's own presumption (like that of his plainly more accomplished colleague Steven Weinberg) ${ }^{15}$ regarding the finished adequacy of science as critically perfect and quite literally beyond critique. This totalising confidence in science has sometimes been saddled by critics with a suffix — calling it scientism ${ }^{16}$ — to hold it at a critical distance from more nuanced views on science. But in the context of philosophy or sociology of science, etc., a charge of scientism is about as much a reproof as the charge of deism in a religious community. Thus the effect of the hoax was consummate in and by the (all too moralising) moral of the story and the same joke continues to work in the wake of the unremittingly monotone commentary on the story and (surprise, surprise) no one who writes on it can be found to say anything but 'how wonderful' 17 it was just to think how Sokal rode into town to show up the postmoderns, the Derrideans, the feminists, the anthropologists and sociologists of science, the social constructivists-at which point, in a spontaneous reflex of reflexivity, certain scholars are then to be seen busily shoring up their own legacy by severing their own work from any even putatively or remotely science-critical perspective. ${ }^{18}$

The philosopher of science, one can only be led to believe, must eschew critique if he or she is to be taken as 'knowing anything' about science. Thus, in the past, one has ruled out the philosophical perspective of a Nietzsche or a Heidegger or even the later Husserl. One cannot be, and one must affirm that one has never been, a member of any such critical party. It is to his credit that Fuller underlines the upshot of this ongoing paradigmatic scheme in the philosophy of science whereby 'any radical philosophical criticism of science has come to be associated with irrationalism' (Fuller 2000, p. 36). And irrationalism, it goes without saying, is a bad thing.

\section{Kuhn: genesis of a paradigm}

Famously, and this is why we are able in the insular context of English-language philosophy of science to quibble about Fleck's influence on Kuhn in the first place, Kuhn did indeed read Fleck's The Genesis and Development of a Scientific Fact (Fleck 1935), as part of his own scholarship and as part of the preparation for his own work on The Structure of Scientific Revolutions (Kuhn 1970 [1962]). Because, as Kuhn reports in retrospect, he read German only 'badly', he was compelled, as he also emphasises, to read and re-read Fleck. ${ }^{19}$

I read it as of great significance that Kuhn's encounter with Fleck took place in an intensifying constellation of ideological circumstances characteristic of the cold war, an era that today can seem as distant from us as Fleck's own vanished Lemberg/Lvov. I read this significance very differently than does Fuller who traces a patently conservative tack throughout. It is important to stress the difference in emphasis, for Fuller makes much of the Cold War context of Kuhn's thought yet fails to advert to the difference this climate could make in Kuhn's own terminology as a transformation of Fleck's own language. 
Kuhn's time, the time that generates our own time, spanned prewar and wartime history and Kuhn's crucial and formative intellectual work found expression during the era of the postwar world known as the cold war. In America proper, the climate of the cold war reflected the still virulent McCarthyism dominating everything from art to criminal justice and including the academy-or Ivory Tower as it was then unquaintly regarded. If the McCarthy era in the land of the free and the brave was not Stalinism, it nevertheless had exactly repressive parallels. Much of the social and intellectual repression characterising the 1950s and 1960s expressed this climate of fear. The change that began to take place in the late 1960s (really into the 1970s and, alas, coming there to an unsung and unmarked dead end) saw a world change in fashion and life-styles, if not in politics. But if today we no longer hear about the socialist or communist threat-to use the cold war's language-that is not because we have become more nuanced about the psychoanalytic projection implicit in the language of a 'communist threat' or about the multifarious and complex dimensionality of political forms like socialism or communism, but rather because like so many of the varied biological species that have become extinct in the long course of the last century, the threat of socialism/communism has been vanquished. The end of the cold war corresponds to the extirpation of the political regimes of socialism and communism itself, almost like the phantasm of democracy in the US. ${ }^{20}$ But current political regimes make it plain that we've not quite evolved beyond the inanity of McCarthyism.

Kuhn, it is well known, if also more vigorously asserted in German-language studies of Fleck's influence on Kuhn than it is in English contexts, did not fully credit Fleck's influence on his work. I argue that Fleck's influence was collimated by the word 'paradigm' as a term Kuhn used to render that same influence. But, and this is the heart of the so-called authorial fallacy, words have lives and fortunes of their own, often alien to their originators, perniciously so in the case of Kuhn's 'paradigm'-where one scholar has counted and many more have alluded to the variety of senses at play in Kuhn's usage. ${ }^{21}$

Kuhn, however, had good political reasons for his periphrastic adaptation of Fleck because the word 'paradigm' served for Kuhn to convey what Fleck expressed by means of ideologically problematic terms like 'thought collective' and 'thought style'. Fleck's conceptual schematisation of 'thought style/collective' presented Kuhn with a research palimpsest, interpretive armature, or background structure for The Structure of Scientific Revolutions, offering Kuhn an exactly deployable heuristic device for articulating the historical course of scientific change or revolution in science. As Kuhn himself rightly emphasises in his 1976 introduction to Fleck's Genesis and Development of a Scientific Fact, ${ }^{22}$ Kuhn was in need of just such a structure for his own study - and it was otherwise unavailable.

This genesis also explains why Kuhn himself was never able adequately to specify the meaning of or to defend or even to understand or accept a conceptual constellation only first discovered in Fleck. ${ }^{23}$ It also explains the parallel resistance to these same ideas in philosophy of science as such. As Lothar Schäfer (1977, p. 25) reflects: 'keeping Kuhn's thorough-going dependency on Fleck in mind, one must draw the obvious conclusion that the key presupposition for [the concept per $s e$ of] revolution in the philosophy of science has to be found in the ahistorical consciousness' of philosophy of science. ${ }^{24}$ This lack of historical sophistication (this would be Wissenchaftichkeit in the German sense of the term and internal to the discipline of history itself) in philosophy of science accounts in many ways for the 
notion of the 'scientific revolution' as a 'fact' so intriguingly contrary to the complex dynamic of the empirical history of science. ${ }^{25}$

It is important to emphasise that I am not claiming a case of intellectual theft. It is my claim that given the political climate of the 1950s and in spite of the obvious relevance of Fleck's study, Kuhn, even had he wished to, could not have invoked Fleck's name because Kuhn could not deploy Fleck's language. Thus to say that Kuhn's 'paradigm' is a periphrastic construction rendering Fleck's Denkstil/Denkkollektiv claims not that Kuhn intentionally plagiarised Fleck's ideas but only that at the time, and on more than one level, Kuhn could make only such a periphrastic allusion to Fleck. ${ }^{26}$

Thus the problem of citing Fleck for Kuhn was not a consequence of Fleck's 'Polish-inflected' German-as Fuller repeats the claim on Kuhn's behalf, surveying the historical circumstances of Kuhn's life and work, this is a misleading assertion on Kuhn's part (Fuller 2000, p. 60n) - for there is no 'false friend', as language teachers say, to trip one up in the translation of Denkstil (thought style) or Denkkollektiv (thought collective). Not a problem of translation but the political restrictions of Kuhn's era (from the forties through the fifties and early sixties) would entail that Kuhn could not adequately refer to Fleck's terminology. Kuhn in his 1962 book could not have used such dangerously loaded terms as 'thought collectives' - or 'thought styles' - for the perfectly banal reasons we still attribute to and name 'politics'. The language of collectives or thought styles would have evoked precisely reactive reactions in a time of the paranoia and anxieties expressed in words like brainwashing, propaganda, the Iron Curtain and the Iron State, and the inscrutable evil of Eastern Europe, of Russia and (this is all that is left today) China. And in 1976, the later Kuhn, writing an introduction to the belated translation of Fleck's book, remained careful to underscore his personal, exactly gut distance from these very same terms. Even after so much time, one may hear the echo of Western anxiety vis-à-vis the image of the 'collective' as the antiindividualist, veritably mindless, socialist 'horde'.

In this way, the then-times themselves engendered the unhappy coinage of the term paradigm-among whatever other reasons there may also have been for the term. This same historical echo reverberates through Kuhn's own revealingly overfrank, at times uncomprehending, sometimes brittle autobiographical reflections. And in The Road Since Structure, in Kuhn's interview with Aristides Baltas, Kostas Gavroglu, and Vassili Kindi, even the most hermeneutically impoverished reader must note the relevance of Kuhn's most repeated word 'anger' (Kuhn 2000, pp. 255-323) - articulating his actions in terms of a fundamental, choleric impatience. This reflexive reaction to his own academic legacy does not contradict as much as it complements the contextual circumstances (or very Fleckian 'genesis') of Kuhn's book, as Fuller outlines it in his own study of Kuhn and the development of Kuhn's own influence in the broader culture of the academy itself. $^{27}$

In this context, it is worth recalling the anecdote that Kuhn found significant enough to dedicate a great proportion of his own brief introduction to Fleck to retelling it. Kuhn reports that his own mentor, Harvard President James Bryant Conant, who became US High Commissioner for Germany, referred to the German title of Fleck's book, Die Entstehung und Entwicklung einer wissenschaftliche Tatsache, in conversation with a German associate, after Kuhn had related his discovery of Fleck to him. For Conant, the borrowed reference backfired, as such borrowed 
references often do in transcultural contexts. Conant's German associate responded to the mention of the title of Fleck's work with a spontaneous denunciation of the concept as such: recoiling from its titular proposition in a bravely, determinedly naïve positivism that is the unchanged ideal of philosophy of science, latterly called realism, then betrayed by the stolid conviction that the-facts-are-the-facts. By definition, as Conant's Teutonic interlocutor painstakingly instructed him, and hence contra the concept of Entstehung and Entwicklung - the one thing Tatsachen or 'facts' did not as such have was anything like a 'genesis' and the last thing they are able to do is 'develop'. Facts are just 'discovered' as what they plainly are. Sidestepping such debacles, Kuhn eschewed Fleck's terminology and he spoke instead of paradigms and paradigm shifts, of normal and of revolutionary science. ${ }^{28}$

The debate that is often gathered under the rubric of the two cultures continues (Fuller makes reference to it), but common analyses of the divide between these cultures inevitably miss the issues at stake. ${ }^{29}$ The problem is what I've been calling incommensurability, it is, to switch paradigmatic reference from Fleck to my own studies of Nietzsche's and Heidegger's philosophic inquiry into science and technology, what Nietzsche claims as the limits between what one can see or know (via what one brings to an inquiry from the outset [Babich 1999a; cf. 1994]) and the upshot of this perspectival constraint for one's capacity for new knowledge, that is, nothing less than scientific discovery.

Language, paradigm, thought style - all are words for such world making (and breaking) limitations. But to exceed a limitation, one must first take account of it. The blindered style of the 'received view' in philosophy of science has proven to be singularly incapable of such a reflexive critique. The great achievement of Fuller's book is that it points to the importance of social studies of science and technology, including history and hermeneutics. To this extent, Fuller stands in the same tradition as Fleck and possibly even Nietzsche, if it is also true that Fuller's omission of Fleck (and so many other names) betrays the Todschweigerei that is the other side of censorship. A more inclusive account would seem a liberating, no: an enlightening prospect for the future of science and technology studies as for philosophy of science.

\section{Acknowledgements}

Part of the material drawn upon in this review appears in a more comprehensive text, 'From Fleck's Denkstil to Kuhn's Paradigm: Conceptual schemes and incommensurability', International Studies in the Philosophy of Science, 17, 2003. I am grateful to James W. McAllister for his constructive suggestions.

\section{Notes}

1. See Fuller (2002).

2. See Fuller (2000, pp. 121 and 304); see, however, p. 212 for an ameliorating note.

3. Fuller refers to Heelan's work on perception (Heelan 1983) in a note on Fuller (2000, p. 53).

4. Trenn (1979). Oddly, enough, Fuller would almost do the same for Mannheim's influence on Fleck as he does for that of Fleck on Kuhn as Fuller makes much of the fact that Fleck does not expressly allude to Mannheim (2000, p. 60n). But, of course, as a strong proponent of Science and Technology Studies (his chapter VII is all about this, under the rubric of 'Kuhnification as ritualised 
political impotence', Fuller, pp. 318-378), Fuller knows better. Today's English-language practice of documentation (Social Science style or otherwise) is not the only way of making references (esoteric allusion seems to be a national sport for the French, for one notorious contemporary example), but and, in general, references that are common knowledge are not commonly tied to a specific name, especially where such a limitation would have been inaccurate.

5. Note, however, that Fuller wavers in this conviction of the lesser relevance of Fleck's importance for Kuhn when he refers to Gustave Le Bon's invention of mass psychology (Fuller 2000, p. 295n), and perhaps he wavers as he does because he shares certain claims (or sympathies) with the original 'professional sociologists' (as Fuller denominates them) who first reviewed Fleck's book and were 'disturbed by his use of the term "collective", with its strong industrial socialist overtones' (Fuller 2000, p. $211 \mathrm{n})$.

6. See my introductory essay discussing Patrick Heelan's work in the philosophy of quantum physics for a discussion of this example referring to both Hanson and Gadamer in the context of objectivity and phenomenology (Babich 2002b). See Toulmin (2002) for a discussion of Gadamer and Heelan.

7. By incommensurability here and in what follows, I refer to the simple badness of fit between Fleck's terminology and conceptual schemata in related areas of the philosophy of science, per se. This is also the sense in which Alasdair MacIntyre (1981, p. $8 \mathrm{ff}$.) speaks of 'conceptual incommensurability' and the general sense in which Hacking (1983, pp. 12-14) characterises it precisely with reference to Kuhn. I thus do not refer to the more specialised use of the term and the correspondingly vast literature addressed to it in analytic philosophy and philosophy of science (just for a start, see Hacking's own reference list (Hacking 1983, p. 278), in addition to Fuller's own discussion, scattered throughout his study, but esp. Fuller (2000, pp. 201-202) and on C.I. Lewis, Fuller (2000, p. 266 ff, and particularly p. 271)).

8. Fuller can do this as noted above, rather than refer to Heidegger, who uses similar language, or Husserl or else Wittgenstein or even Nietzsche, because Fuller is talking about a possible influence on the very specific and very exclusive conceptual world that is that of the philosophy of science.

9. For his part, Baldamus (1979, p. 232) explains the sociological process of the dissemination of ideas from Fleck to Kuhn as follows: 'Als schließlich die Bedeutung Flecks von Kuhn entdeckt wurde, führte dessen eigenmächtige Verarbeitung des Fleckschen Gedankenguts zu einem verblüffenden Rezeptionserfolg. Indem Kuhn aus dem Werk Flecks nur solche Bestandteile übernahm, die sich sinngemäß den Bedürfnissen der sechziger Jahre anpassen ließen, wurde jene Kritik [gemeint ist Flecks radikale Kritik an der zeitgenössischen Wissenschaftsphilosophie] entschärft und dadurch im Prinzip erst diskutabel, d. h. rezeptionsfähig'.

10. In opposition to the contemporary Western cultural emphasis on the scientific genius, as Fleck himself observes: 'scientists, most frequently individualists, do not want to see the collective nature of thinking. What would remain of their renowned genius?' (Fleck, 1986 [1947], p. 151). For this reason, Fleck's critical notion of thought collectives, as intrinsic to the progress of science as such, contradicts the dominant, historically ideological ideal of scientific genius and the achievement of Western liberal individualism. See Harré (2002) and Ziman (2002); see also Ziman (1995). But, beyond this, see further Golinski (1998).

11. Kockelmans (1975) has explored the relation between the conception of science within the natural and social sciences, to show that, however counterintuitively for some, the natural sciences constitute not only the theoretical paradigm for the social sciences but the historical precedent for the same. The social sciences are not more primitive or less developed versions of the natural sciences and are thus not developmentally prior to them. This also means that such sciences ought not be expected to evolve increasingly more mathematical or logicised variants of themselves in the future.

12. See, for example, studies offering a sociology of 'laboratory life' or the 'manufacture of knowledge'. See Bruno Latour's more or less uncomprehending, certainly pained efforts to make his own proscience orientation as clear as possible (Latour, 1999).

13. For an instanciation of this new trend internal to the philosophy of science (qua logical empiricism) see Giere and Richardson (1996) as well as Friedman (1999, 2000); for earlier examples directed to history of science as such, see Cohen (1994), Crombie (1952), Hacking (1992), and Jardine (1991). Fuller discusses and critiques Butterfield's legacy in Fuller (2000, pp. 23ff.)

14. I take this report, a perfect piece of gossip, on perfect faith. Hearsay is hearsay.

15. See for a specific discussion of this credulity-and its limits-MacIntyre (1999), pp. xv-xvii.

16. Sorrel (1991).

17. How could it happen that scientists not be asked to vet an article on science-as if the evening news did not constantly present scientists happily saying speculative things about genetic engineering or evolution unmasked or debunked by other scientists just as happily as misleading, overstated, and even erroneous. See for an overview and fuller discussion, Babich (2002a); an earlier version appeared as Babich (1997).

18. Hacking (1999); Latour (1999).

19. Note that Kuhn's self-deprecation indicates a language competence that itself requires a hermeneutic articulation, different from the circumstance that is rather more common among 
today's American philosophers who cannot read German at all. In the same way, we note Kuhn also reports that he likewise read and spoke French very haltingly, a facility which was likewise different from illiteracy, as his own autobiographical reflections make clear in his recollection of his time during and after World War II in France where what he, as a military expert, was able to do then required just as much ability in French as he similarly disavows with a scientist's characteristic diffidence-a point of self-deprecating irony further attested by the praise of the quality of his French which he received from Parisians.

20. This insight is hardly a resultant of recent events, but it is now unmistakable in the wake of the dramatic demonstration of the limits of that same image of 'democracy' afforded by the very events of the 2000 US presidential election and judicial decision regarding the undecided results of the same. This continues now in the wake of the terrorist attach of $9 / 11$ and the complex global politics between American and Islamic cultures.

21. Masterman (1970). Fuller himself coins the word 'paradigmatitis' to take the consequences of this famously labile term a bit further afield (2000, p. 318).

22. See too the more comprehensive introduction by Schäfer and Schnelle in Fleck (1980, pp. viixlvii).

23. This would mean, to oppose the reading expressed by Schäfer (1977) in his reflections on Fleck's reception by comparison with Kuhn's own influence, that at the very least, such a reliance shows less Kuhn's prescience than his opportunism.

24. Schäfer thus explicates the very problem of contemporary analytic philosophy of science as the dominant thought style possible in and for philosophy of science (Wissenschaftstheorie). For Schäfer, Kuhn is little more than Fleck's more marketable (or, as Baldamus expressed it: rezeptionsfähig) epigone. See Schäfer (1977).

25. See Cohen (1994) as well as Hacking (1992) and, as if to prove that this reduces to textbook level cliché, Shapin (1996). It is important to note that the 'very idea' of the history of science remains conceptually problematic in the context of the history of science-and in many ways, it continues to be so, if we are to believe Jardine's mild and all-too-conservative warning (Jardine 2000 [1991]), and we should. A recent review of the disciplinary relationship between the philosopy of science and the history of science shows that this tension remains-although it is manifestly clear that the philosophy of science can no longer insist, as a reconstructivist perspective could argue (to wit, Lakatos's famous quip), that it is all to the worse for science if it does not in historical fact accord with theoretical accounts of the logic of scientific discovery or invention. And if talk of thought collectives and thought styles was problematic, to combine the former with the idea of the history (specifically, fatally, expressed as the genesis and development) of a fact was exactly shocking to the logical mindset of the philosophy of science.

26. Kuhn could not credit Fleck beyond his famous prefatory characterisation of Fleck's book as 'an essay that anticipates many of my own ideas' and situating those same 'ideas' in what Kuhn (1970, p. vii) called 'the sociology of the scientific community'. To the great disappointment of students of sociology of science, it is intriguing that (but Fuller himelf despite his brief for STS neglects to discuss this) Kuhn ultimately failed to specify or further to expand upon this allusion to the 'sociology of the scientific community'.

27. Fuller (2000).

28. As Fleck's notion of thought style implies, and just as Nietzsche argues, Kuhn could find in Fleck only what he had eyes to see, or ears to listen for. Hence, what exceeded Kuhn's capacity for understanding he simply overlooked. Kuhn's mistake lay-and with regard to Fleck I contend that he had only one mistake, it was also singularly pernicious-in assuming that the history and sociology of ideas was a properly established or developed discipline with a patent and received structure. A scientist by training and not a historian, Kuhn could not have guessed that nothing could be further from the truth in the social dynamic one author has famously dramatised as the 'two cultures' and the still enduring abyss between the same.

29. See my essay expressing this debate in terms of the analytic continental divide interior to professional philosophy Babich (2003b).

\section{References}

Babich, B., 1994, Nietzsche's Philosophy of Science: Reflecting Science on the Ground of Art and Life (Albany: State University of New York Press).

BAвICH, B., 1997, The hermeneutics of a hoax. Common Knowledge, 6(2), 23-33.

Вавісн, В., 1999a, Nietzsche's critical theory: the culture of science as art, in: B. Babich (ed.), Nietzsche, Epistemology, and the Philosophy of Science: Nietzsche and the Sciences, Boston Studies in the Philosophy of Science, vol. 204 (Dordrecht: Kluwer), pp. 1-13.

Babich, B. (ed.), 1999b, Nietzsche, Epistemology, and the Philosophy of Science: Nietzsche and the Sciences, Boston Studies in the Philosophy of Science, vol. 204 (Dordrecht: Kluwer). 
BAвICH, B., 2002a, Sokal's hermeneutic hoax: physics and the new inquisition. In B. Babich (ed.), Hermeneutic Philosophy of Science, Van Gogh's Eyes, and God: Essays in Honor of Patrick A. Heelan, S. J., Boston Studies in the Philosophy of Science, vol. 225 (Dordrecht: Kluwer), pp. 67-78.

Babich, B. (ed), 2002b, Hermeneutic Philosophy of Science, Van Gogh's Eyes, and God: Essays in Honor of Patrick A. Heelan, S. J., Boston Studies in the Philosophy of Science, vol. 225. (Dordrecht: Kluwer).

Вавісн, B., 2003a, From Fleck's Denkstil to Kuhn's paradigm: conceptual schemes and incommensurability. International Studies in the Philosophy of Science, 71, 75-91.

Вавісн, B., 2003b, On the analytic continental divide in philosophy: Nietzsche's lying truth, Heidegger's speaking language, and philosophy. In C. G. Prado (ed.), A House Divided: Comparing Analytic and Continental Philosophy (Amherst, NY: Prometheus/Humanity Book), pp. 63-103.

Baldamus, W., 1977, Ludwik Fleck and the development of the sociology of science. In P. R. Gleichmann, J. Goudsblom et al. (eds), Human Figurations: Essays for Norbert Elias (Amsterdam: Rodopi).

Baldamus, W., 1979) Das exoterische Paradox der Wissenschaftsforschung. Ein Beitrag zur Wissenschaftstheorie Ludwik Flecks, Zeitschrift für allgemeine Wissenschaftstheorie, 10, 213-233.

Baltas, A., Gavroglu, K. and Kindi, V., 2000, A discussion with Thomas Kuhn. In J. Conant and J. Haugeland (eds), The Road Since Structure: Philosophical Essays, 1970-1993, with an Autobiographical Interview (Chicago, IL: University of Chicago Press), pp. 255-323.

Cohen, H. F., 1994, The Scientific Revolution: A Historiographic Survey (Chicago, IL: University of Chicago Press).

Cohen, R. S. and Schnelle, T. (eds), 1986, Cognition and Fact: Materials on Ludwik Fleck, Boston Studies in the Philosophy of Science, vol. 87 (Dordrecht: Reidel).

Crombie, A. C., 1952, Augustine to Galileo: The History of Science, AD 1100-1700 (London: Heinemann).

Dorobiski, A., 1987, Zur Wissenschafts- und Erkenntnisauffassung von Ludwik Fleck (Dissertation, HumboldtUniversität Berlin).

Dunem, P., 1913-1959, Le Système du monde: Histoire des doctrines cosmologiques de Platon à Copernic (Paris: Hermann).

FLECK, L., 1979, The Genesis and Development of a Scientific Fact, trans. F. Bradley and T. J. Trenn (Chicago, IL: University of Chicago Press).

FLECK, L., 1980 [1935], Die Entstehung und Entwicklung einer wissenschaftliche Tatsache (Frankfurt am Main: Suhrkamp).

FLECK, L., 1986 [1947], To look, to see, to know. In R. S. Cohen and T. Schnelle (eds), Cognition and Fact: Materials on Ludwik Fleck, Boston Studies in the Philosophy of Science, vol. 87 (Dordrecht: Reidel), pp. 129-151.

Fleck, L., 1986 [1960], Crisis in science. In R. S. Cohen and T. Schnelle (eds), Cognition and Fact: Materials on Ludwik Fleck, Boston Studies in the Philosophy of Science, vol. 87 (Dordrecht: Reidel), pp. 153-158.

Friedman, M., 1999, Reconsidering Logical Positivism (Cambridge: Cambridge University Press).

Friedman, M., 2000, Parting of the Ways: Carnap, Cassirer, Heidegger (Chicago, IL: Open Court).

Fuller, S., 2000, Thomas Kuhn: A Philosophical History for Our Times (Chicago, IL: University of Chicago Press).

Fuller, S., 2002, A catholic stance toward scientific inquiry for the $21^{\text {st }}$ century. In B. Babich (ed.), Hermeneutic Philosophy of Science, Van Gogh's Eyes, and God: Essays in Honor of Patrick A. Heelan, S. J., Boston Studies in the Philosophy of Science, vol. 225 (Dordrecht: Kluwer), pp. 399-425.

Giere, R. N. and Richardson, A. W. (eds), 1996, Origins of Logical Empiricism (Minneapolis: University of Minnesota Press).

Golinski, J., 1998, Making Natural Knowledge: Constructivism and the History of Science (Cambridge: Cambridge University Press).

HACKING, I., 1982, Language, truth and reason. In M. Hollis and S. Lukes (eds), Rationality and Relativism (Oxford: Oxford University Press), pp. 48-66.

Hacking, I., 1983, Representing and Intervening (Cambridge: Cambridge University Press).

Hacking, I., 1992, 'Style' for historians and philosophers. Studies in History and Philosophy of Science, 23, $1-23$.

Hacking, I., 1999, The Social Constuction of What? (Cambridge, MA: Harvard University Press).

Harré, R., 2002, Science as the work of a community. In R. Babich (ed.), Hermeneutic Philosophy of Science, Van Gogh's Eyes, and God: Essays in Honor of Patrick A. Heelan, S. J., Boston Studies in the Philosophy of Science, vol. 225. (Dordrecht: Kluwer), pp. 219-229.

Heelan, P. A., 1983, Space-Perception and the Philosophy of Science (Berkeley and Los Angeles, CA: University of California Press).

HeElan, P. A., 1965, Quantum Mechanics and Objectivity: The Physical Philosophy of Werner Heisenberg (The Hague: Nijhoff).

Jardine, N., 2000 [1991], The Scenes of Inquiry (Oxford: Oxford University Press).

Kockelmans, J. J., 1975, Toward an interpretive or hermeneutic social science. Graduate Faculty Philosophy Journal, 5, 73-96.

Kunn, T. S., 1970 [1962], The Structure of Scientific Revolutions (Chicago, IL: University of Chicago Press). 
Kunn, T. S., 1979, Foreword. In L. Fleck (ed.), The Genesis and Development of a Scientific Fact, trans. F. Bradley and T. J. Trenn (Chicago, IL: University of Chicago Press), pp. vi-xi.

Kunn, T. S., 2000, In J. Conant and J. Haugeland (eds), The Road Since Structure: Philosophical Essays, 1970-1993, with an Autobiographical Interview (Chicago, IL: University of Chicago Press).

Latour, B., 1999, Pandora's Hope: Essays on the Reality of Science Studies (Cambridge, MA: Harvard University Press).

MacInTyRe, A., 1981, After Virtue (London: Duckworth).

MacIntyre, A., 1999, Preface. In B. Babich (ed.), Nietzsche, Epistemology, and the Philosophy of Science: Nietzsche and the Sciences, Boston Studies in the Philosophy of Science, vol. 204 (Dordrecht: Kluwer), pp. $\mathrm{xv}-\mathrm{xvii}$.

Masterman, M., 1970, The nature of a paradigm. In I. Lakatos and A. Musgrave (eds), Criticism and the Growth of Knowledge (Cambridge: Cambridge University Press), pp. 59-89.

Merton, R. K., 1977, The sociology of science: an episodic memoir. In R. K. Merton and J. Gaston (eds), The Sociology of Science in Europe (Carbondale, IL: Southern Illinois University Press).

Nietzsche, F., 1980, Kritische Studienausgabe (Berlin: Walter de Gruyter).

Shapin, S., 1996, The Scientific Revolution (Chicago, IL: University of Chicago Press).

SCHÄFER, L., 1977, Theorien-dynamische Nachlieferungen. Anmerkungen zu Kuhn-Sneed-Stegmüller, Zeitschrift für philosophische Forschung, 31, 19-42.

Schäfer, L. and Schnelle, T., 1980, Einleitung. In L. Fleck (ed.), Die Entstehung und Entwicklung einer wissenschaftliche Tatsache (Frankfurt am Main: Suhrkamp), pp. vii-xlvii.

Schäfer, L. and Schnelle, T., 1983, Die Aktualität Ludwik Flecks in Wissenschaftssoziologie und Erkenntnistheorie. In L. Schäfer and T. Schnelle (eds), Ludwik Fleck: Erfahrung und Tatsache. Gesammelte Aufsätze (Frankfurt am Main: Suhrkamp), pp. 9-34.

Schnelle, T., 1982, Ludwik Fleck. Leben und Denken. Zur Entstehung und Entwicklung des soziologischen Denkstils in der Wissenschaftsphilosophie (Freiburg im Breisgau: Hochschulsammlung Philosophie).

Schnelle, T., 1986, Microbiology and philosophy of science. Lwow and the German Holocaust. Stations of a life: Ludwik Fleck (1896-1961). In R. S. Cohen and T. Schnelle (eds), 1986, Cognition and Fact: Materials on Ludwik Fleck, Boston Studies in the Philosophy of Science, vol. 87 (Dordrecht: Reidel), pp. $3-36$.

Sorrel, T., 1991, Scientism: Philosophy and the Infatuation with Science (London: Routledge).

Toulmin, S., 2002, The hermeneutics of the natural sciences. In B. Babich (ed), Hermeneutic Philosophy of Science, Van Gogh's Eyes, and God: Essays in Honor of Patrick A. Heelan, S. J., Boston Studies in the Philosophy of Science, vol. 225. (Dordrecht: Kluwer), pp. 25-29.

Trenn, T. J., 1979, Preface. In L. Fleck (ed.), The Genesis and Development of a Scientific Fact, trans. F. Bradley and T. J. Trenn (Chicago, IL: University of Chicago Press), pp. xii-xix.

Tsouyopoulos, N., 1982, Auf der Suche nach einer adäquaten Methode für die Geschichte und Theorie der Medizin. Auseinandersetzung mit Ludwik Flecks 'Entstehung und Entwicklung einer wissenschaftlichen Tatsache', Medizinhistorisches Journal, 17, 20-36.

Winneke, S., 1992, Ludwik Fleck-Zur Wirkung eines Wirkungslosen, Arbeitskreis für Wissenschaftsgeschichte: Dialogo (Stuttgart).

Zајісек, G., 1992, Ludwik Fleck: founder of the philosophy of modern medicine. Cancer Journal, 5/6, 304-305.

Ziman, J., 1995, Of One Mind: The Collectivization of Science (Woodbury, NY: American Institute of Physics).

Ziman, J., 2002, No man is an island. In B. Babich (ed), Hermeneutic Philosophy of Science, Van Gogh's Eyes, and God: Essays in Honor of Patrick A. Heelan, S. J., Boston Studies in the Philosophy of Science, vol. 225. (Dordrecht: Kluwer), pp. 203-217. 